\title{
Impact of HR Practices on Employee Engagement among Machine Operators in the Large Apparel Industry in Sri Lanka
}

\author{
Pinto, HPASU and Thalgaspitiya, UK
}

\begin{abstract}
Area of the Study

This study is mainly focused on examining the impact of HR practices on employee engagement among machine operators in the large apparel industry in Sri Lanka.

\section{Problem of the Study}

There is an empirical gap of how HR practices affect to employee engagement in the Sri Lankan context. Therefore researchers addressed: How HR practices affect employee engagement among machine operators in the large apparel industry in Sri Lanka?

\section{Method of the study}

The data were collected from a randomly selected sample of 384 machine operators who are employed in top three companies in the large Sri Lankan apparel industry. A structured questionnaire which included Bakar's (2013) 16 items for measuring HR practices and Bakker, et al.' (2002) 17 items for measure employee engagement was administered. The data were analyzed using Pearson'sCorrelation and simple regression analysis.
\end{abstract}

\section{Findings of the Study}

The findings exhibited that there is a positive relationship between HR practices and employee engagement among machine operators in the large apparel industry in Sri Lanka. As well as HR practices of the Sri Lankan large apparel industry companies are at a satisfactory level and employee engagement of machine operatorsare at a high level. Moreover, all dimensions of HR practices are positively and significantly correlated with employee engagement, namely selective staffing, reward system, performance appraisal, comprehensive training and employee participation program. Lastly, the regression analysis between HR practices and employee engagement indicated that $59.8 \%$ of total variance of employee engagement was explained by HR practices.

\section{Conclusion of the Study}

It is concluded that there is a positive impact of HR practices on employee engagement among machine operators in the large apparel industry in Sri Lanka. Thus organizations in this sector need to develop proper and well-structured HR practices to attain high employee engagement level among the machine operators.

Keywords: HR Practices, Employee Engagement, Machine Operators

\section{Introduction}

Carnegie (2012) said that the best products and services, strategies, technologies and better cost structures of organization contribute to superior performance but all of them can be copied over time by other firms. The workforce of the companyis another essential thing which is needed to create competitive advantage and it can also be considered as the factor that cannot be duplicated or imitated by other rivals (Carnegie 2012; Anitha 2014). Because 
of high demand and shortage of skillful employees, employee engagement has becomeas important an issue as employee turnover (Basbous 2011). According to the Gallup research report (2003) engaged employees work harder and smarter, and they will be better for the organization than those who turn up and do merely what they are obliged to do. According to the Department of Census and Statistics in Sri Lanka in 2013, the apparel sector is the highest industrial employment generator in Sri Lanka. As a result of high employment in the apparel industry, employee engagement is another important HRM activity of the apparel industry today. There are many HR practices that are used by managers to recruit, select, develop, utilize, reward, and maximize the potential of human resources in organizations (Megginson, et al. 1995) and HR practices are the significant contributor to employee engagement (Bhatnagar 2007; Saks 2006; Shuck, et al. 2011 and Tomlinson 2010). Therefore, if there are good HR practices in an organization they will positively related to its level of employee engagement.

\section{Problem Background and Problem of the Study}

Towers Watson consultancy firm (2012) conducted a global workforce survey and they found out that $35 \%$ of all worldwide employees were highly engaged, $22 \%$ of employees were unsupported (Employees who are traditionally engaged but lack the support and/or energy for sustainable engagement), 17\% of employees were detached (Employees who feel supported and/or energized but lack a sense of traditional engagement) and $26 \%$ of employees were actively disengaged in their jobs. Aon Hewitt also discussed about trends in global employee engagement and according to Hewitt (2015) in 2014 the global average employee engagement level was 62\%. Gallup research report (2013) is another survey about the nature and causes of employee engagement and how companies can improve engagement to enhance business performance. This survey based on 142 countries and found out that $13 \%$ of employees were engaged in their jobs, while $63 \%$ were not engaged and $24 \%$ are actively disengaged. However, all of the above surveys discussed that average engagement levels vary by different global regions, industries and job types and that the same factors or methods cannot be used to motivate employees to engage with their work and that they are different from country to country.According to Gallup research findings (2013) in South Asian countries only $10 \%$ of employees are engaged in their jobs, while $61 \%$ are not engaged and $29 \%$ are actively disengaged. Also this survey indicated that only $14 \%$ of Sri Lankan employees are engaged, while $62 \%$ are not engaged and $24 \%$ are disengaged in their jobs. Moreover this survey found out that only $7 \%$ of manufacturing employees in South Asian countries are engaged, while $65 \%$ are not engaged and $28 \%$ are actively disengaged in their jobs. Therefore low levels of employee engagement are a crucial problem in South Asia.

By the majority accounts, employee engagement influences productivity, profitability, employee retention and customer services (Zigarmi, et al. 2009; Xanthopoulou, et al. 2009). Gallup research findings (2013) showed that, work units which are in the top $25 \%$ of their Q12 Client Database have considerably high productivity, profitability, and customer ratings, less turnover and absenteeism, and fewer safety incidents than those in the bottom $25 \%$. So they mentioned engaged employees as the lifeblood of organizations. Also they identified 
employee engagement positively affects employees' work lives as well as their non-work lives and finally engaged employees are more optimistic about the economy.

According to Heikkeri (2010), organizations should give concentration to the employee disengagement trend as well, because it has immense impact on both the worker and employer. Bakker and Demerouti (2008) said that disengaged employees have negative feelings and health problems more often than engaged workers and also they can influence their colleagues to transfer negative emotions. Disengaged employees do not recommend their company as a place to work and promote company's products or services less often (Baumruk 2004). In addition to that Krueger and Killham (2007) found that disengaged employees were less innovative and creative and did not like to share new ideas with coworkers. According to Robinson (2010), low level of engagement caused to anxiety and depression in employees. Furthermore, the Gallup research report (2003) measured that actively disengaged workers are 10 times more likely to say they will leave their organizations within a year than engaged staff. Harter, et al. (2009) found that absenteeism was $37 \%$ higher in organizations scoring in the bottom $25 \%$ on engagement.

According to the above details, employee engagement is a very significant area for every industry today. As Robinson, et al. (2004), there has been unexpectedly small academic and empirical research on this topic. There are a number of models and theories in literature which provide a framework for how to improve employee engagement (Bakker \& Demerouti 2008; Kahn 1990 and May, et al. 2004). However, the academic literature has not properly addressed how the employees' level of satisfaction as regards human resource practices of the organization impact their engagement level (Jose and Mampilly 2012). Therefore, it seems that there is a gap theoretically as well as empirically, especially in Sri Lanka with regard to the impact of HR practices on employee engagement among machine operators in Sri Lankan large apparel industry. Therefore, the problem addressed in this study is to reveal the impact of HR practices on employee engagement among machine operators in the large apparel industry in Sri Lanka.

\section{Literature Review}

\section{HR Practices}

HRM practices have been defined in several aspects (Tan \& Nasurdin 2010). As cited by Tan and Nasurdin (2010), Schuler and Jackson (1987) defined HRM practices as methodsto attract, develop, motivate, and retain employees to ensure the effective implementation and the survival of the organization and its members. Lado and Wilson (1994) viewed HR practices as a set of distinct and interrelated activities, functions, and processes with the intention to attract, develop and maintain the human resources of organization. Karsnia (2009) defined HRM practices as, "organizational activities directed at managing the pool of human resource and ensuring that the resources are employed towards the fulfillment of organizational goals” (p.15). Besides, HRM practices are also conceptualized as a set of internally consistent policies and practices designed and implemented to ensure the contribution of a firm's human capital for achieving its business objectives (Delery \& Doty 
1996). Likewise, Minbaeva (2005) viewed HRM practices as a set of practices used by an organization to cope employees through facilitating the development of capabilities that are firm specific, produce complex social relation and generate organization knowledge to sustain competitive advantage. Megginson, et al. (1995) said that, there are many HR practices that are used by managers to recruit, select, develop, utilize, reward and maximize the potential of human resources in organizations. The relationship between human resource practices and work outcomes is an increasingly researched topic in human resource management (Edgar \& Geare 2005; Truss, et al. 2013; Petrescu \& Simmons 2008 and Kashefi 2009).

\section{Employee engagement}

Employee engagement has emerged as a popular concept and it has been defined in various ways (Jose \& Mampilly 2012). In 1990, Kahn introduced the concept of employee engagement. He defined personal engagement as "the harnessing of organization members' selves to their work roles; in engagement, people employ and express themselves physically, cognitively, and emotionally during role performances" (Kahn 1990 p.694). Kahn (1990) also noted that "the uncoupling of selves from work roles; in disengagement, people withdraw and defend themselves physically, cognitively, or emotionally during role performances" (p.694). Burnout researchers defined engagement as the opposite side of burnout (Maslach, et al. 2001). Maslach, et al. (2001) noted that "engagement is characterized by energy, involvement, and efficacy, the direct opposite of the three burnout dimensions of exhaustion, cynicism, and inefficacy". Employee engagement is also considered in the milieu of organizational behavior. Therefore Schaufeli et al. (2002) defined engagement as a positive, fulfilling, work-related state of mind that is characterized by vigor, dedication, and absorption. Harter et al. (2002) were the first who looked at employee engagement at the business unit level. In their conceptualization, employee engagement was defined as an "individual's involvement and satisfaction with as well as enthusiasm for work" (Harter, et al. 2002, p. 417). Robinson, et al. (2004) viewed employee engagement as a positive attitude held by the employee towards their organization and its values. The first academic research to specifically conceptualize and test antecedents and consequences of employee engagement occurred in 2006 (Saks 2006). There employee engagement was defined as "a distinct and unique construct consisting of cognitive, emotional, and behavioral components associated with individual role performance" (Saks 2006, p.602). Albrecht (2010) conceptualized employee engagement as a positive and energized work- related motivational state and a genuine willingness of employees to contribute to work role and organizational success. However there is no universally accepted definition for employee engagement and research has shown that it is a multi-faceted construct (Kahn 1990). Moreover the relevance of employee engagement has been increased and as a result of it, researchers are now focusing on what exactly drives engagement and how it can be enhanced (Jose \& Mampilly 2012). 


\section{Research Framework}

\section{Selective staffing}

According to Kahn (1990), Macey and Schneider (2008), Christian, et al. (2011) and Vance (2006), there is a positive relationship between selective staffing and employee engagement. Hence, the first hypothesis of the study was developed as:

$\mathrm{H}_{1}$ : $\quad$ Selective staffing is positively related to employee engagement among machine operators in large apparel industry in Sri Lanka.

\section{Reward system}

According to Bhattacharya and Mukherjee (2009), Dale-Olson (2006) and Gottlied (2011), there is a positive relationship between the reward system and employee engagement. Hence, the second hypothesis of the study was developed as:

$\mathrm{H}_{2}$ : Reward system is positively related to employee engagement among machine operators in large apparel industry in Sri Lanka.

\section{Performance Appraisal}

Albrecht et al. (2015), Mone and London (2010), Similarly Barbier et al. (2013), Bakker, et al. (2004), May et al. (2004), Schaufeli and Bakker (2004) and Gupta and Kumar (2013) demonstrated that there is a positive relationship between performance appraisal and employee engagement. Hence, the third hypothesis of the study was developed as:

$\mathrm{H}_{3}$ : Performance Appraisal is positively related to employee engagement among machine operators in large apparel industry in Sri Lanka.

\section{Comprehensive Training}

Mone and London (2009), Luthans et al. (2010), Schaufeli and Salanova (2008), Salanova et al. (2010) and Gruman and Saks (2011) argued that there is a positive relationship between comprehensive training and employee engagement. Hence, the fourth hypothesis of the study was developed as:

$\mathrm{H}_{4}$ : Comprehensive Training is positively related to employee engagement among machine operators in large apparel industry in Sri Lanka.

\section{Employee Participation Program}

According to Bakker and Demerouti (2007) and Konrad (2006), there is a positive relationship between the employee participation program and employee engagement. Hence, the fifth hypothesis of the study was developed as:

$\mathrm{H}_{5}$ : Employee Participation Program is positively related to employee engagement among machine operators in large apparel industry in Sri Lanka.

However HR policies and practices do not exist in isolation and they are interrelated to one another (Bakar 2013). Boxall and Purcell (2000) also said that the effectiveness of individual HRM practices is based on the nature of other HRM practices and business strategy. Furthermore many past studies have deliberated that HR practices are significant contributors to work engagement (Bhatnagar 2007; Saks 2006; Shuck, et al. 2011 and Tomlinson 2010). 
Further the study of Thavakumar and Nawaratne (2015) reveals that there is a positive relationship between HRM practices and work engagement. Hence, the sixth hypothesis of the study was developed as:

$\mathrm{H}_{6}$ : $\quad \mathrm{HR}$ practices are positively related to employee engagement among machine operators in large apparel industry in Sri Lanka.

This research framework mainly highlights the relationship between two variables. HR practices are considered as an independent variable and employee engagement is considered as a dependent variable of the study. Figure 01 depicts the relevant schematic diagram of the research framework.

Figure 1: Schematic Diagram of the Research Framework.

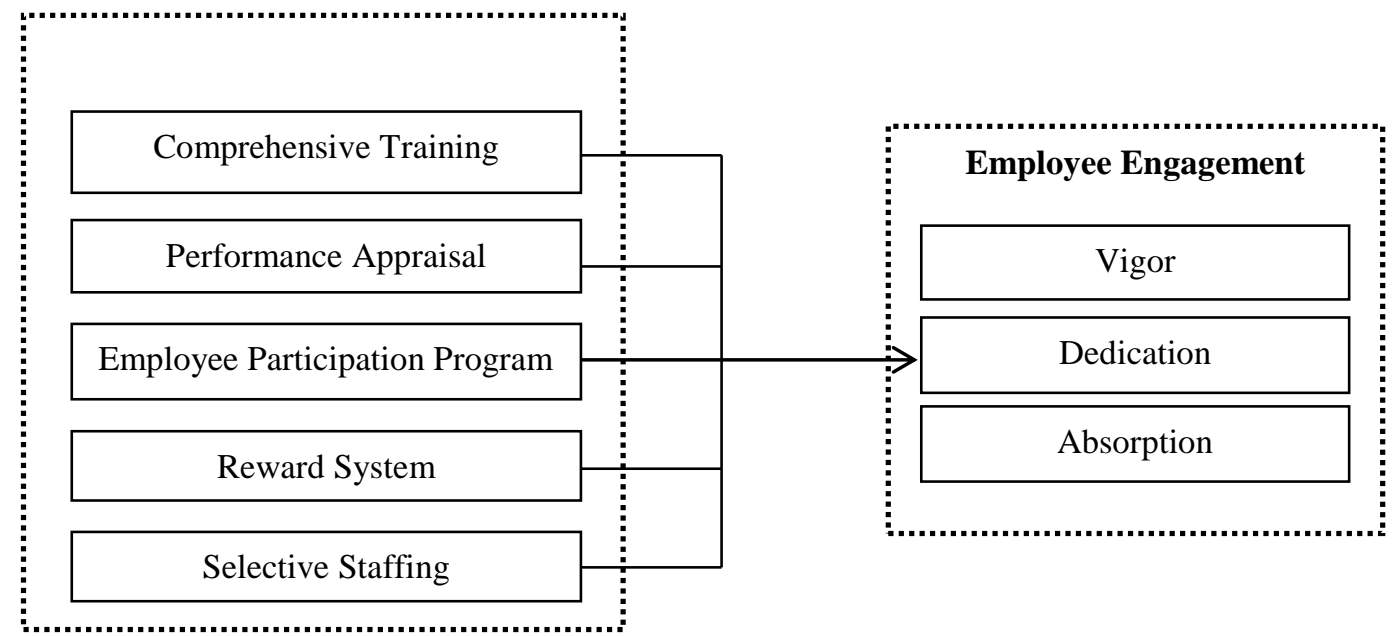

\section{Methodology}

This study attempted to find out the impact of HR practices on employee engagement among machine operators inlarge apparel industry in Sri Lanka. So the objective of the study was to establish the significant relationship between the independent variable and dependent variable. Therefore the type of the investigation of this study is co-relational. According to Sekaran (2010), correlation studies are done in non-contrived field setting with minimum researcher interference. Co-relational studies are also called field studies. This study was a field study because it examined the impact of HR practices on employee engagement of machine operators in the natural working environment of the apparel industry. None of the variables were controlled or manipulated. As the study was conducted in a natural environment where work proceeds normally, this was a non- contrived setting and no any artificial or contrived setting was created for the study. This study took over one month for data collection. The data for the study was collected within the particular time period and there were no subsequent extension of the research contemplated. Hence the study was cross sectional in nature. For this study, the data was collected from each individual. Thus, the unity of the study was individual: machine operators who were employed in the top three companies in the Sri Lankan large apparel industry. 
The population of the study was machine operators who were employed in the top three companies in large apparel industry Sri Lanka and the total population size was 95000 . Sample size was 384 (Krejcie and Morgan Table 1970) and the sample method of the survey was simple random sampling. In this study both primary and secondary data collection methods were used. A questionnaire was used as a primary data collection method and the secondary data were collected from the various sources such as organization reports, books, journals, government reports, the internet and other publications.

HR practices and employee engagement were measured through anquestionnaire with five point scales, which were completed by the respondents themselves approximately according to their experience. The variables of the study constituted interval scales.

The independent variable of the study was HR practices of large apparel industry companies in Sri Lanka, which was measured by an instrument consisting of 16 statements developed by Bakar in 2013. The HR practices were measured in terms of five dimensions which were comprehensive training, performance appraisal, employee participation program, reward system and selective staffing. These dimensions consisted of 12 aspects which werecomprehensive training (T\&D Practices, T\&D Procedure, T\&D Policy), performance appraisal (Performance Evaluation Method, Personal Development),employee participation program (Participative Decision Making), reward system (Performance Based Reward System,Competitiveness) and selective staffing (Selection Policy, Selection Practice). HR practices were measured by using the machine operators' responses to the questionnaire with five point Likert scales of strongly agree, agree, neither disagree nor agree, disagree and strongly disagree.

The dependent variable of the study was employee engagement of machine operators in the large apparel industry in Sri Lanka, which was measured by an instrument consisting of 17 statements developed by Schaufeli, Salanova, Gonzalez- Roma and Bakker in 2002. Employee engagement was measured in terms of three dimensions as vigor, dedication and absorption. These dimensions consisted of 13 aspects as vigor (Bursting, Vigorous, Willingness, Persistence, Mental resilience, Perseverance), dedication (Meaningfulness, Enthusiastic, Inspiration, Proud, Challenging), absorption (Concentration, Engrossment). Employee engagement was measured by their responses to the questionnaire with five point Likert scales of strongly agree, agree, neither disagree nor agree, disagree and strongly disagree.

The internal item consistency reliability was examined with Cronbach's Alpha test. The result of it is given in Table 01, which suggests that the internal reliability of each instrument was satisfactory. 
Table 01: Results of Test

\begin{tabular}{|c|l|c|}
\hline & Instrument & Cronbach's Alpha \\
\hline 1 & HR Practices & 0.889 \\
\hline 2 & Employee Engagement & 0.967 \\
\hline
\end{tabular}

The content validity of the instruments was ensured by the conceptualization and operationalization of the variables using the available literature by the high internal consistency reliability of the instruments as denoted by the Alphas.

Data collected from the primary source (Questionnaire) were analyzed using the computer based statistical data analysis package, SPSS (version 16.0) for validity, reliability and relationship testing. The data analysis included univariate and bivariate analyses.

\section{Results}

To investigate the responses for independent and dependent variables of the machine operators of the large apparel industry, univariate analysis was used. The results of the univariate analysis are given in Table 02.

Table 02: Univariate Analysis

\begin{tabular}{|c|c|c|c|c|c|c|c|}
\hline & 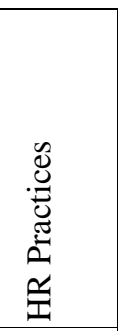 & 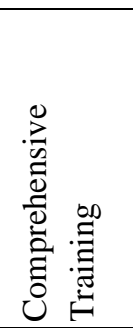 & 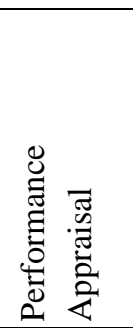 & 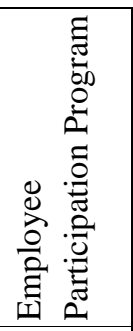 & 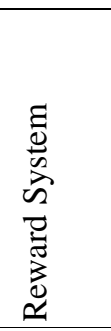 & 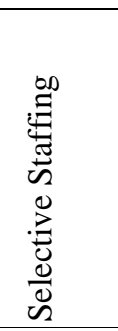 & 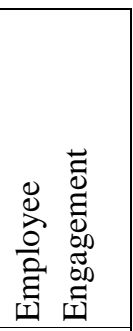 \\
\hline Mean & 4.0099 & 3.9727 & 3.9479 & 3.8906 & 4.0417 & 4.0762 & 4.1059 \\
\hline Median & 4.1333 & 4.0000 & 4.0000 & 4.0000 & 4.0000 & 4.0000 & 4.2353 \\
\hline Mode & 3.53 & 4.00 & 4.00 & 4.00 & 4.00 & 4.00 & 4.53 \\
\hline Std. Deviation & .56114 & .62260 & .75004 & .76716 & .58475 & .60289 & .61146 \\
\hline Variance & .315 & .388 & .563 & .589 & .342 & .363 & .374 \\
\hline Skewness & -.292 & -.244 & -.008 & -.021 & -.235 & -.107 & -.819 \\
\hline Std. Error of Skewness & .125 & .125 & .125 & .125 & .125 & .125 & .125 \\
\hline Kurtosis & -.985 & -.887 & -1.106 & -.847 & -.915 & -.585 & .035 \\
\hline Std. Error of Kurtosis & .248 & .248 & .248 & .248 & .248 & .248 & .248 \\
\hline Minimum & 2.67 & 2.50 & 2.50 & 2.00 & 2.75 & 2.50 & 2.00 \\
\hline Maximum & 4.87 & 5.00 & 5.00 & 5.00 & 5.00 & 5.00 & 5.00 \\
\hline
\end{tabular}

According to Table 02, the data recorded for the HR practices and its dimensions and employee engagement are approximately normally distributed. The mean value of the HR 
practices is 4.0099. The dimensions of HR practices namely selective staffing, reward system, performance appraisal, comprehensive training and employee participation program have mean values of 3.9727, 3.9479, 3.8906, 4.0417 and 4.0762 respectively and all mean values are greater than the average mean value. Therefore HR practices of Sri Lankan large apparel industry companies are at satisfactory level.The mean value of employee engagement is 4.1059 and it indicates that employee engagement of machine operators is in high level.

Pearson's Product Moment Correlation with one tailed test of significance was used to investigate the relationship between HR practices and employee engagement. Table 03 presents the results of the correlation test.

Table 03: Pearson's Correlation

\begin{tabular}{|l|l|l|}
\hline Variables & correlation & Sig. (i-tailed) \\
\hline Selective Staffing & $.688^{* *}$ & 0.000 \\
\hline Reward System & $.675^{* *}$ & 0.000 \\
\hline Performance Appraisal & $.672^{* *}$ & 0.000 \\
\hline Comprehensive training & $.712^{* *}$ & 0.000 \\
\hline Employee Participation Program & $.634^{* *}$ & 0.000 \\
\hline HR Practices & $.773^{* *}$ & 0.000 \\
\hline **. Correlation is significant at the 0.01 level (1-tailed).
\end{tabular}

As shown in Table 03, Pearson's correlation coefficient between HR practices and employee engagement is 0.773 and it can be said that there is a positive relationship between HR practices and employee engagement. Moreover dimensions of HR practices represent the positive values of Pearson's correlation coefficients. Therefore, it indicated that HR practices and its dimensions are positively and significantly correlated to employee engagement.

The results of simple regression analysis of the independent variable and its dimensions against the dependent variable are given in Table 04 .

Table 04: Simple Linear Regression Analysis

\begin{tabular}{|c|c|c|c|c|c|c|}
\hline & 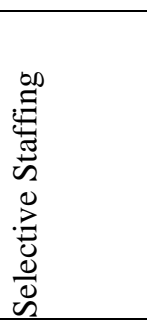 & 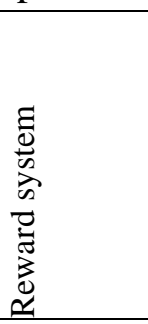 & 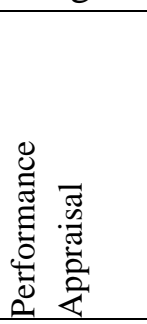 & 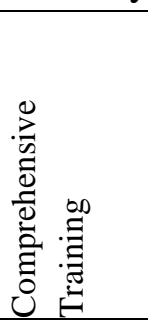 & 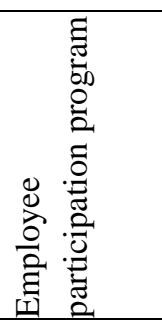 & 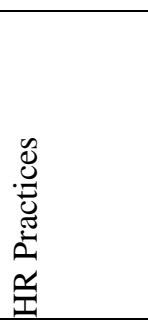 \\
\hline R Square & .474 & .456 & .452 & .507 & .402 & .598 \\
\hline Adjusted R Square & .472 & .454 & .451 & .506 & .401 & .597 \\
\hline $\mathrm{F}$ & 343.745 & 319.772 & 315.050 & 393.044 & 257.290 & 567.480 \\
\hline Significance & $.000^{\mathrm{a}}$ & $.000^{\mathrm{a}}$ & $.000^{\mathrm{a}}$ & $.000^{\mathrm{a}}$ & $.000^{\mathrm{a}}$ & $.000^{\mathrm{a}}$ \\
\hline B- constant & 1.261 & 1.253 & 1.942 & 1.327 & 2.139 & .728 \\
\hline b-value & .698 & .706 & .548 & .699 & .506 & .842 \\
\hline
\end{tabular}


According to the results in Table 04, regression coefficient (b) of HR practices and employee engagement is 0.842 indicating that approximately $59.8 \%$ of the variance of employee engagement can be accounted for through HR practices. Also, HR practices are significantly related to employee engagement, where $F$ value is 567.480. Furthermore, each dimension of HR practices, selective staffing, reward system, performance appraisal, comprehensive training and employee participation program are significantly related to employee engagement.

All the results of correlation analysis and simple regression analysisfor each hypothesis were summarized in Table 05.

Table 05: Summary results of each hypotheses testing

\begin{tabular}{|l|c|c|c|c|l|}
\hline \multirow{2}{*}{ Hypotheses } & \multicolumn{2}{|l|}{$\begin{array}{l}\text { correlation } \\
\text { coefficients }\end{array}$} & \multicolumn{2}{l|}{ regression coefficient } & $\begin{array}{l}\text { Accepted } \\
\text { accepted } \\
\text { Of the hypotheses }\end{array}$ \\
\cline { 2 - 5 } & $\mathrm{r}$ & $\mathrm{p}$ & $\mathrm{b}$ & $\mathrm{p}$ & Accepted \\
\hline Hypothesis 1 & .688 & 0.000 & .698 & 0.000 & Accepted \\
\hline Hypothesis 2 & .675 & 0.000 & .706 & 0.000 & Accepted \\
\hline Hypothesis 3 & .672 & 0.000 & .548 & 0.000 & Accepted \\
\hline Hypothesis 4 & .712 & 0.000 & .699 & 0.000 & Accepted \\
\hline Hypothesis 5 & .634 & 0.000 & .506 & 0.000 & Accepted \\
\hline Hypothesis 6 & .772 & 0.000 & .842 & 0.000 & \\
\hline
\end{tabular}

As indicated in Table 05, all the hypotheses were accepted according to the results of correlational and simple regression analyses.

\section{Discussion and Conclusion}

The main intention of this research was to ascertain the impact of HR practices on employee engagement of machine operators in Sri Lankan large apparel industry. According to the results of simple regression analysis, HR practices were found to have a positive impact on employee engagement with strength of $b$ value being 0.842 . It showed that two variables were strongly linearly related, as HR practices increased, employee engagement also increased. In addition to that dimensions of HR practices were also found to have positive impact on employee engagement. The $b$ value of selective staffing, reward system, performance appraisal, comprehensive training and employee participation program are $0.698,0.706,0.548,0.699$ and 0.506 respectively which indicated the strength of impact. Further, the relationship between HR practices and employee engagement was still positive and significant at the 0.01 level. The correlation between these variables was 0.773 . Furthermore dimensions of HR practices also represented the positive values of Pearson's correlation coefficients. Therefore results of the hypotheses test on the relationship between HR practices and employee engagement revealed that HR practices and all the five dimensions of HR practices were positively related to employee engagement.

Moreover, according to the findings of frequency distribution analysis, Sri Lankan large apparel industry companies have a satisfactory level of HR practices and employee 
engagement of machine operators in these companies is at high level.Thus organizations in this sector need to develop proper and well-structured HR practices in order to attain high employee engagement level among machine operators.

The findings of this research study will be important on the theoretical level as well as in practical scenarios. As this research model was substantiated, HR practices highly influenced on level of employee engagement of machine operators in this industry. Thus it emphasizes the necessity of development and implementation of sound HR practices to improve the engagement of employees. Therefore HR mangers should be more concerned about HR practices to ensure high level of engagement among employees.

The researcher wishes to suggest some areas for future studies. First, future research will be recommended to use longitudinal designs to avoid causal relationship biases. Second, it is recommended that multiple sources of data be used for future research in this area, such as quantitative or qualitative data including archival data from organizational records to overcome social desirability response bias. The findings of this study may not be generalized to apparel industry companies in other contexts or other cultures and research in other settings or geographical areas might yield different results. So it is recommended to use the present findings across different contexts.

\section{References}

i. Albrecht, SL 2010, Handbook of employee engagement, Edward Elgar, Cheltenham, UK.

ii. Albrecht, SL, Bakker, AB, Gruman, JA, Macey, WH \& Saks, AM 2015, 'Employee engagement, human resource management practices and competitive advantage', Journal of Organizational Effectiveness: People and Performance. vol. 2, pp.7-35.

iii. Anitha, J 2014, 'Determinants of employee engagement and their impact on employee performance', International Journal of Productivity and Performance Management, vol. 63, pp.308-323.

iv. Aon Hewitt 2015, 2015 Trends in global employee engagement, Aon Plc.

v. Bakar, RA 2013, 'Understanding factors influencing employee engagement: a study of the financial sector in Malaysia' PhD Thesis, RMIT University.

vi. Bakker, AB and Demerouti, E 2007, 'The job demands-resources model: state of the art', Journal of Managerial Psychology, vol. 22, pp.309-328.

vii. Bakker, AB, Demerouti, E \&Verbeke, W. 2004, 'Using the job demands: resources model to predict burnout and performance', Human Resource Management, vol. 43, pp. 83-104.

viii. Bakker, AB. and Demerouti, E 2008, 'Towards a model of work engagement', Career Development International, vol. 13, no. 3, pp. 209-223.

ix. Barbier, M, Hansez, I, Chmiel, N \&Demerouti, E 2013, 'Performance expectations, personal resources, and job resources: how do they predict work engagement?', European Journal of Work and Organizational Psychology, vol. 22, pp. 750-762. 
x. Basbous, OK 2011, 'Antecedents of employee engagement'MBA Thesis, University Sains Malaysia.

xi. Baumruk, R 2004, 'The missing link: the role of employee engagement in business success', Workspan, vol. 47, no. 11, pp.48-52.

xii. Bhatnagar, J 2007, 'Talent management strategy of employee engagement in Indian ITES employees: Key to retention', Employee Relations, vol. 29, no. 6, pp.640-663.

xiii. Bhattacharya, S \& Mukherjee, P 2009, 'Rewards as a key to employee engagement: A comparative study on I.T. professionals', ASBM Journal of Management, vol. 2, no. 1.

xiv. Boxall, P \& Purcell, J 2000, 'Strategic human resource management: where have we come from e where should we be going?', International Journal of Management Reviews, vol. 2, no. 2, pp.183-203.

xv. Carnegie, D 2012, 'What drives employee engagement and why it matters', Carnegie Training White Paper.

xvi. Christian, MS, Garza, AS \& Slaughter, JE 2011, 'Work engagement: a quantitative review and test of its relations with task and contextual performance', Personnel Psychology, vol. 64, pp.89-136.

xvii. Dale-Olsen, H 2006, 'Wages, fringe benefits and worker turnover', LabourEconomics, vol.13, no. 1, pp.87-105.

xviii. Delery, JE \& Doty, HD 1996, 'Modes of theorizing in strategic human resource management: tests of universalistic, contingency, and configurational performance predictions', Academy of Management Journal, vol. 39, no. 4, pp. 802-835.

xix. Department of Census \& Statistics \& Ministry of Finance and Planning 2013, Quarterly report of the Sri Lankan labour force survey, DCSMP, second quarter.

xx. Edgar, F \&Geare, A 2005, 'HRM practice and employee attitudes: different measures -different results', Personnel Review, vol. 34, no. 5, pp. 534-549.

xxi. Gallup 2003, 'The State of the global workplace: employee engagement insights for business leaders worldwide', Gallup Inc, Washington.

xxii. Gallup 2013, 'Thestate of the global workplace: employee Engagement insights for business leaders worldwide', Gallup Inc, Washington.

xxiii. Gottlied, H 2011, 'Benefit wizard: Engages and guides', Benefits Magazine, vol. 39, pp.32-43.

xxiv. Gruman, JA \& Saks, AM 2011, 'Performance management and employee engagement', Human Resource Management Review, vol. 21, pp. 123-136.

xxv. Gupta, V \& Kumar, S 2013, 'Impact of performance appraisal justice on employee engagement: a study of Indian professionals', Employee Relations, vol. 35, pp.61-78.

xxvi. Harter, JK, Schmidt, FL \& Hayes, TL 2002, 'Business-unit-level relationship between employee satisfaction, employee engagement, and business outcomes: A metaanalysis', Journal of Applied Psychology, vol. 87, p.268-279.

xxvii. Harter, JK, Schmidt, FL, Killham, EA \&Agrawal, STL 2009, 'Q12® Meta-Analysis: the relationship between engagement at work and organizational outcomes', Journal of Applied Psychology.

xxviii. Heikkeri, E 2010, 'Roots and Consequences of the Employee Disengagement Phenomenon', Master's Thesis. Saimaa University. 
xxix. Jose, G \&Mampilly, SR 2012, 'Satisfaction with HR practices and employee engagement: a social exchange perspective', Journal of Economics and Behavioral Studies, vol. 4, no. 7, pp.423-43.

xxx. Kahn, WA 1990, 'Psychological conditions of personal engagement and disengagement at work', Academy of Management Journal, vol. 33, no. 4, pp. 692724.

xxxi. Karsnia, EJ 2009, 'Best practices for employee engagement', A Research Paper, University of Wisconsin-Stout.

xxxii. Kashefi, M 2009, 'Job satisfaction and/or job stress: the psychological consequences of working in'high performance work organisations', Current Sociology, vol. 57, pp. 809-828.

xxxiii. Konrad, A 2006, 'Engaging employees through high-involvement work practices', Ivey Business Journal.

xxxiv. Krueger, J \&Killham, E 2007, 'The innovation equation', Gallup Management Journal.

xxxv. Lado\& Wilson, MC 1994, 'Human resource systems and sustained competitive advantage: a competency based perspective', Academy of Management, vol. 19, pp.699-728.

xxxvi. Luthans, F, Avey, JB, Avolio, BJ \& Peterson, SJ 2010, 'The development and resulting performance impact of positive psychological capital', Human Resource Development Quarterly, vol. 21, pp.41-67.

xxxvii. Macey, WH \& Schneider, B 2008, 'The meaning of employee engagement, Industrial and Organizational Psychology: Perspectives on Science and Practice', Journal of Management, vol.1, pp.3-30.

xxxviii. Maslach, C, Schaufelli, WB \&Leiter, MP 2001, 'Job burnout', Annual Review of Psychology, vol. 52, pp.397-422.

xxxix. May, DR, Gilson, RL \& Harter, LM 2004, 'The psychological conditions of meaningfulness, safety and availability and the engagement of the human spirit at work', Journal of Occupational and Organizational Psychology, vol. 77, pp.11-37.

xl. Megginson, LC, Franklin, GM, \& Byrd, MJ 1995, Human resource management, TX: Dame Publications, Houston.

xli. Minbaeva, DB 2005, 'HRM practices and MNC knowledge transfer', Personal Review, vol. 34, no. 1, pp. 125-144.

xlii. Mone, EM \& London, M 2009, Employee engagement through effective performance management: a manager's guide, Routledge, New York.

xliii. Mone, EM \& London, M 2010, Employee engagement through effective performance management: a practical guide for managers, Routledge, New York.

xliv. Petrescu, AI \& Simmons, R 2008, 'Human resource management practices and workers' job satisfaction', International Journal of Manpower, vol. 29, no. 7, pp. 651 667.

xlv. Robinson, D, Perryman, S \&Hayday, S 2004, The Drivers of Employee Engagement, Institute for Employment Studies, Brighton. 
xlvi. Robison, J. 2010, 'Disengagement can be really depressing', Gallup Management Journal.

xlvii. Saks, AM 2006, 'Antecedents and consequences of employee engagement', Journal ofManagerial Psychology, vol. 21, no. 7, pp.600-619. doi: 10.1108/02683940610690169

xlviii. Salanova, M, Schaufeli, WB, Xanthopoulou, D \& Bakker, AB 2010, 'The gain spiral of resources and work engagement: sustaining a positive worklife', in Bakker, AB and Leiter, MP (Eds), Work Engagement: A Handbook of Essential Theory and Research, Psychology Press, New York.

xlix. Schaufeli, WB \& Bakker, AB 2004, 'Job demands, job resources, and their relationship with burnout and engagement: a multi-sample study', Journal of Organizational Behavior, vol. 25, pp.293-315.

1. Schaufeli, WB \&Salanova, M 2008, 'Enhancing work engagement through the management of human resources', in Näswall, K, Hellgren, J and Sverke, M (Eds), The Individual in the Changing Working Life, Cambridge University Press, New York.

li. Schaufeli, WB, Martinez, IM, Pinto, AM, Salanova, M \& Bakker, AB 2002a, 'Burnout and engagement in university students: a cross-national study', Journal of Cross-Cultural Psychology, vol. 33, no. 5, pp. 464-481.

lii. Schaufeli, WB, Salanova, M, Gonzalez-Roma, V \& Bakker, AB 2002b, 'The measurement of engagement and burnout: a two sample confirmatory factor analytic approach', Journal of Happiness Studies, vol. 3, no. 1, pp. 71-92.

liii. Sekaran, U 2013, Research methods for business: a skill building approach, $3^{\text {rd }}$ edn, John Wiley \& Sons, Inc., New York.

liv. Shuck, MB, Rocco, TS \&Albornoz, CA 2011, 'Exploring employee engagement from the employee perspective: implications for HRD', Journal of European Industrial Training, vol. 35, no. 4, pp.300-325.

lv. Tan, CL \&Nasurdin, AM 2010, 'Human resource management practices and organizational innovation: an empirical study in Malaysia', Journal of Applied Business Research, vol. 2, no. 4, pp. 105-115.

lvi. Thavakumar, D \&Nawaratne, NNJ 2015, 'The relationship between Human Resource Management Practices and Work Engagement in Sri Lankan Insurance Industry', International Journal of Research (IJR), vol. 2, no. 3, pp.601-614.

lvii. Tomlinson, G 2010, 'Building a culture of high employee engagement', Strategic HR Review, vol. 9, no. 3, pp.25-31.

lviii. Tower Watson, 2012, 'Engagement at risk: driving strong performance in a volatile global environment', Global Workforce Study.

lix. Truss, C, Shantz A, Soane, E, Alfes, K \&Delbridge, R 2013, 'Employee engagement, organisational performance and individual well-being: exploring the evidence, developing the theory', The International Journal of Human Resource Management, vol. 24, no. 14, pp. 2657-2669. 
ISSN: $2012-7227$

1x. Vance, RJ 2006, Employee engagement and commitment: a guide to understanding, measuring and increasing engagement in your organization: SHRM Foundation, Alexandria.

1xi. Xanthopoulou, D et al. 2009, 'Work engagement and financial returns: a diary study on the role of job and personal resources', Journal of Occupational and Organizational Psychology, vol. 82, no. 1, pp.183-200.

lxii. Zigarmi, D, Nimon, K, Houson, D, Witt, D \& Diehl, J 2009, 'Beyond engagement: toward a framework and operational definition for employee work passion', Human Resource Development Review, vol. 8, no. 3, pp.300-326.

\begin{tabular}{ll}
\hline Pinto, HPASU & $\begin{array}{l}\text { Department of Human Resource Management } \\
\text { University of Sri Jayewardenepura } \\
\\
\text { jhrm@ @jp.ac.lk }\end{array}$ \\
\hline Thalgaspitiya, UK & Senior Lecturer \\
& Department of Human Resource Management \\
& University of Sri Jayewardenepura \\
& jhrm@sjp.ac.lk \\
& $\underline{\text { uktal@ sjp.ac.lk }}$ \\
\hline
\end{tabular}

